\title{
Performance and durability of solid oxide electrolysis cells
}

\author{
Hauch, Anne; Jensen, Søren H; Ramousse, Severine; Mogensen, Mogens Bjerg
}

Published in:

Journal of The Electrochemical Society

Link to article, DOI:

$10.1149 / 1.2216562$

Publication date:

2006

Document Version

Publisher's PDF, also known as Version of record

Link back to DTU Orbit

Citation (APA):

Hauch, A., Jensen, S. H., Ramousse, S., \& Mogensen, M. B. (2006). Performance and durability of solid oxide electrolysis cells. Journal of The Electrochemical Society, 153(9), A1741-A1747.

https://doi.org/10.1149/1.2216562

\section{General rights}

Copyright and moral rights for the publications made accessible in the public portal are retained by the authors and/or other copyright owners and it is a condition of accessing publications that users recognise and abide by the legal requirements associated with these rights.

- Users may download and print one copy of any publication from the public portal for the purpose of private study or research.

- You may not further distribute the material or use it for any profit-making activity or commercial gain

- You may freely distribute the URL identifying the publication in the public portal

If you believe that this document breaches copyright please contact us providing details, and we will remove access to the work immediately and investigate your claim 


\title{
Performance and Durability of Solid Oxide Electrolysis Cells
}

\author{
A. Hauch, ${ }^{\text {a,b,z }}$ S. H. Jensen, ${ }^{\text {a,c }}$ S. Ramousse, ${ }^{a}$ and M. Mogensen ${ }^{\mathrm{a}, *}$ \\ ${ }^{a}$ Ris $\phi$ National Laboratory, Fuel Cells and Solid State Chemistry Department, DK-4000 Roskilde, Denmark \\ ${ }^{b}$ Department of Chemistry, and ${ }^{c}$ Department of Physics, The Technical University of Denmark, \\ DK-2800 Kgs. Lyngby, Denmark
}

Solid oxide fuel cells produced at Ris $\emptyset$ National Laboratory have been tested as electrolysis cells by applying an external voltage. Results on initial performance and durability of such reversible solid oxide cells at temperatures from 750 to $950^{\circ} \mathrm{C}$ and current densities from $-0.25 \mathrm{~A} / \mathrm{cm}^{2}$ to $-0.50 \mathrm{~A} / \mathrm{cm}^{2}$ are reported. The full cells have an initial area specific resistance as low as $0.27 \Omega \mathrm{cm}^{2}$ for electrolysis operation at $850^{\circ} \mathrm{C}$. During galvanostatic long-term electrolysis tests, the cells were observed to passivate mainly during the first $\sim 100 \mathrm{~h}$ of electrolysis. Cells that have been passivated during electrolysis tests can be partly activated again by operation in fuel cell mode or even at constant electrolysis conditions after several hundred hours of testing. (C) 2006 The Electrochemical Society. [DOI: 10.1149/1.2216562] All rights reserved.

Manuscript submitted March 6, 2006; revised manuscript received May 4, 2006. Available electronically July 18,2006

In the perspective of the increasing interest in renewable energy, hydrogen economy, and $\mathrm{CO}_{2}$ neutral energy production, reversible solid oxide cells (SOCs) are a potentially interesting technology. Using a solid oxide electrolysis cell can be a cost effective and efficient way to produce hydrogen by high-temperature electrolysis of steam (HTES). ${ }^{1-4}$ The cells can be operated as solid oxide fuel cells (SOFCs) for electricity production and as solid oxide electrolysis cells (SOEC) to produce hydrogen by high-temperature electrolysis of steam by applying an external voltage. Potentially, such reversible SOCs can be combined with already existing energy technologies. By converting surplus energy from nuclear power plants or renewable energy sources such as wind or solar, the SOCs can optimize the efficiency of such energy technologies and play an important role in the security of supply in future hydrogen-based energy systems. Some of the first results on hydrogen production by HTES using SOCs were reported more than two decades ago, ${ }^{1,2}$ where Dönitz ${ }^{2}$ presented results from the HOTELLY project for a single cell and stack test including durability tests; however the project was stopped around 1990. Since then, intensive research and development in the field of SOFCs has taken place and the efforts have resulted in optimized materials giving high performing, longterm stable cells. ${ }^{5}$ The research within the field of HTES using SOC can easily benefit from the results obtained within the SOFC research.

For SOCs to become interesting from a commercial point of view, a low internal resistance of the cell is important, not only at start-up but also during thousands of hours of electrolysis operation as the hydrogen production price is proportional to the resistance of the cell. So far, only a few results on durability of high-performance SOECs have been reported in literature and even though the operation of the SOCs is reversible and can have comparable initial performance in electrolysis and fuel cell mode, the degree of passivation of the cells during long-term testing in fuel cell and electrolysis operation mode, respectively, can be dramatically different. ${ }^{6}$ Therefore, it is necessary not only to produce high-performance SOECs but also long-term stable electrolysis cells.

Results on performance and durability of SOECs are presented here. Polarization curves (IV curves) at various test conditions have been recorded to monitor the initial performance for both fuel cell and electrolysis operation of the SOCs produced at Risø National Laboratory. Results from galvanostatic long-term electrolysis tests for four SOCs are given and the electrolysis testing is shown to lead to a significant passivation of the cells. A partial activation of an electrolysis tested cell by fuel cell operation is reported. Furthermore, an example is given of a $776 \mathrm{~h}$ electrolysis test, where the passivation of the electrolysis cell was followed by a partial activation at constant electrolysis conditions.

\footnotetext{
* Electrochemical Society Active Member.

z E-mail: anne.hauch@risoe.dk
}

\section{Experimental}

Nickel/yttria-stabilized zirconia (Ni/YSZ) supported DK-SOFC cells were used for the electrolysis tests. The cells are full cells produced at Ris $\varnothing$ National Laboratory. ${ }^{6,7}$ The cells have a 10-15 $\mu \mathrm{m}$ thick hydrogen electrode of Ni/YSZ cermet, a 10-15 $\mu \mathrm{m}$ thick YSZ electrolyte, a 15-20 $\mu \mathrm{m}$ thick strontium-doped lanthanum manganite (LSM-YSZ) composite oxygen electrode, and the cells are supported by a $\sim 300 \mu \mathrm{m}$ thick Ni/YSZ layer. ${ }^{7}$ The ratio between Ni and YSZ (TZ8Y, Tosoh Corporation, $\mathrm{ZrO}_{2}$ stabilized with $8 \mathrm{~mol} \%$ $\mathrm{Y}_{2} \mathrm{O}_{3}$ ) is $40 / 60$ vol \% both for the support layer and the active electrode layer. ${ }^{8}$ The composition of the LSM is $\left(\mathrm{La}_{0.75} \mathrm{Sr}_{0.25}\right)_{0.95} \mathrm{MnO}_{3}$ and the ratio between LSM and YSZ in the composite electrode is LSM $/$ YSZ $=50 / 50$ vol \%. ${ }^{9}$ As illustrated in Fig. 1 (top), the SOCs are planar $5 \times 5 \mathrm{~cm}$ cells with an active electrode area of $16 \mathrm{~cm}^{2}$. One half of the setup for cell testing is illustrated in Fig. 1 (bottom); this includes the alumina housing, current collector (Ni foil), glass sealing, and Ni/YSZ-based gas distributor. The air distributor (LSMbased), current collector (gold foil), and top part of the alumina cell housing is then placed on top to give a cross flow for the gasses. A detailed description of the setup is given elsewhere. ${ }^{10,11}$ At startup,
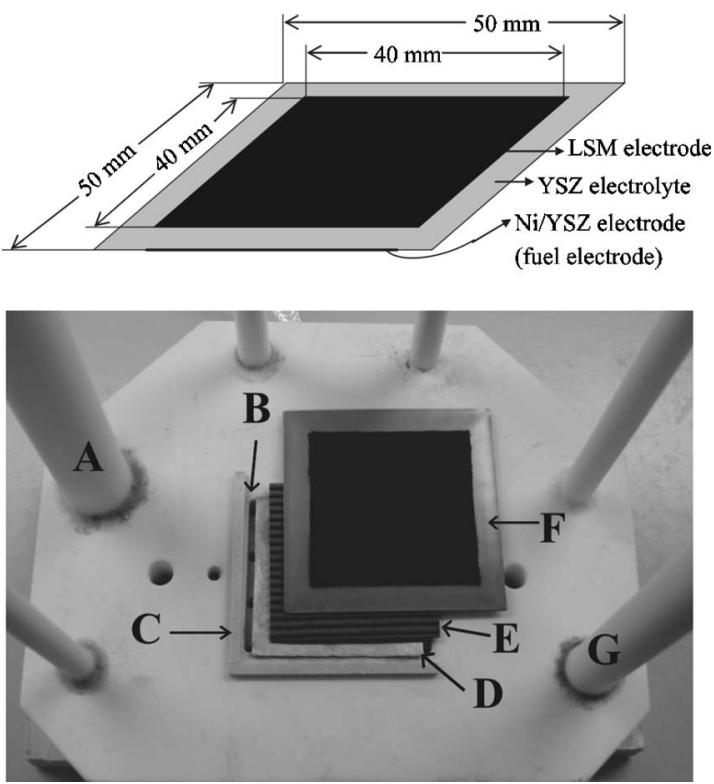

Figure 1. Schematic drawing of the SOCs for the electrolysis tests (top) and photo of the one half of the test setup in an alumina cell house (bottom). A: $\mathrm{H}_{2} \mathrm{O} / \mathrm{H}_{2}$ tube inlet, B: Gas inlet holes for $\mathrm{H}_{2} \mathrm{O} / \mathrm{H}_{2}$, C: Glass sealing, D: Current collector (Ni foil), E: Gas distributor, F: The cell and G: Gas outlet tube. Schematic drawing of the test setup is given in Ref. 11. 


\begin{tabular}{|c|c|c|c|c|}
\hline Test & $\begin{array}{l}\text { Current } \\
\text { density }\end{array}$ & $\begin{array}{c}\text { Steam } \\
\text { conversion }\end{array}$ & Temperature & $\begin{array}{c}\text { Electrolysis } \\
\text { test time }\end{array}$ \\
\hline A & $-0.25 \mathrm{~A} / \mathrm{cm}^{2}$ & $14 \%$ & $750^{\circ} \mathrm{C}$ & $82 \mathrm{~h}$ \\
\hline B & $-0.50 \mathrm{~A} / \mathrm{cm}^{2}$ & $28 \%$ & $950^{\circ} \mathrm{C}$ & $140 \mathrm{~h}$ \\
\hline $\mathrm{C}$ & $-0.50 \mathrm{~A} / \mathrm{cm}^{2}$ & $28 \%$ & $850^{\circ} \mathrm{C}$ & $135 \mathrm{~h}$ \\
\hline D & $-0.25 \mathrm{~A} / \mathrm{cm}^{2}$ & $14 \%$ & $850^{\circ} \mathrm{C}$ & $766 \mathrm{~h}$ \\
\hline
\end{tabular}

the nickel oxide in the $\mathrm{Ni} / \mathrm{YSZ}$ electrode is reduced to nickel in hydrogen at $1000^{\circ} \mathrm{C}$. Before electrolysis is started, the gas passing over the oxygen electrode is changed from air to $10 \mathrm{~L} / \mathrm{h}$ of $\mathrm{O}_{2}$. Thereby $p\left(\mathrm{O}_{2}\right)$ is kept constant at 1 atm when switching from opencircuit voltage (OCV) to electrolysis operation of the cell. This is advantageous for subsequent analysis of the possible changes in the oxygen electrode response observed in the electrochemical impedance spectra recorded during testing. The inlet gas composition to the hydrogen electrode was $p\left(\mathrm{H}_{2} \mathrm{O}\right)=0.7$ atm and $p\left(\mathrm{H}_{2}\right)$ $=0.3 \mathrm{~atm}$ during electrolysis testing for all electrolysis tests reported in this work. This gas composition to the Ni/YSZ electrode is obtained by mixing $6 \mathrm{~L} / \mathrm{h} \mathrm{O}_{2}$ and $17 \mathrm{~L} / \mathrm{h} \mathrm{H}_{2}$ in a gas mixer and leading the mixture to the cell through the inlet tube (Fig. 1). All the gas compositions reported in this work are given as initial fuel compositions at the gas inlet of the cell. The results presented are four SOC electrolysis tests. The tests were performed at various temperatures and current densities. An overview of the electrolysis durability test conditions is given in Table I. The degree of steam conversion given in Table I is calculated as the number of converted water molecules using Faradays law, divided by the total number of $\mathrm{H}_{2} \mathrm{O}$ molecules led to the gas inlet of the cell. For all four tests, the test conditions were kept constant during electrolysis test and the tests were run galvanostatic.

A dc characterization has been performed by recording IV curves for each of the cells before and after the long-term electrolysis tests. The polarization curves were measured using controlled current method stepping $62.5 \mathrm{~mA} /\left(\mathrm{s} \mathrm{cm}^{2}\right)$. The IV curves presented in this work are almost linear and the area specific resistances (ASR) are calculated as the chord from OCV to the voltages measured at given current densities. Where nothing else is stated, data from OCV to +0.75 and $-0.75 \mathrm{~A} / \mathrm{cm}^{2}$, respectively, are included to calculate the ASR values. The ASR values therefore reflect the cell performances over a large polarization range.

$\mathrm{AC}$ characterization was performed by recording electrochemical impedance spectra (EIS). The spectra were recorded applying an ac voltage with amplitude of $12 \mathrm{mV}$ in the frequency range from $82 \mathrm{kHz}$ to $0.82 \mathrm{~Hz}$. A Solartron 1260 frequency analyzer was used for the impedance measurements. To obtain EIS during electrolysis operation of the cells, the analyzer was used in combination with an external shunt to measure the ac current through the cell. ${ }^{12}$ From the EIS, the ohmic resistance $\left(R_{\mathrm{S}}\right)$ was found as the value of the real part of the impedance measured at $82 \mathrm{kHz}$. The polarization resistance $\left(R_{\mathrm{p}}\right)$ is determined as the real part of the impedance at $0.82 \mathrm{~Hz}$ minus the real part of the impedance measured at $82 \mathrm{kHz}$. If the relative error is estimated by comparing the numbers reported here with results from optimal fitting of the same EIS, ${ }^{13}$ the relative errors are $25 \%$ and $6 \%$ for $R_{\mathrm{s}}$ and $R_{\mathrm{p}}$, respectively. The large difference between the $R_{\mathrm{s}}$ given as the real part of the impedance at $82 \mathrm{kHz}$ and the $R_{\mathrm{s}}$ value from optimal fit of the spectra, is due to an inductive response from wires, etc. in the EIS setup. ${ }^{13}$

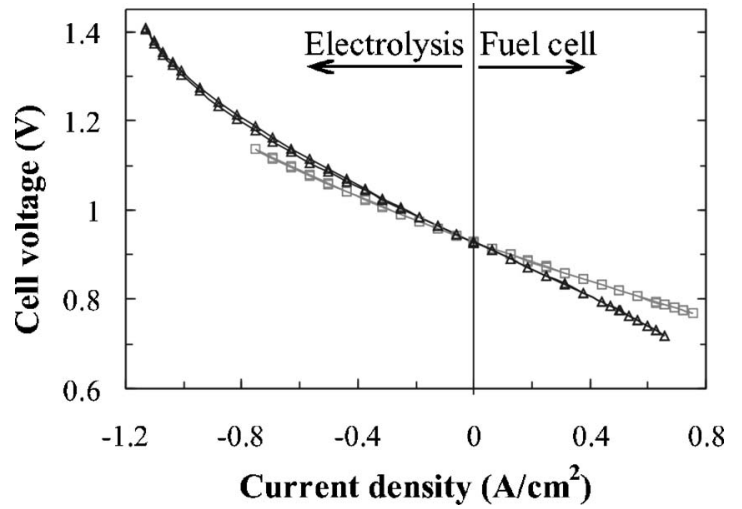

Figure 2. Comparison of IV curves recorded at $850^{\circ} \mathrm{C}$ before the electrolysis testing for the cell used for test $B(\square)$ and test $C(\triangle)$, the cells with the highest and lowest performance. Air was passed over the oxygen electrode and the gas composition to the hydrogen electrode was $p\left(\mathrm{H}_{2} \mathrm{O}\right)=p\left(\mathrm{H}_{2}\right)$ $=0.5 \mathrm{~atm}$.

\section{Results}

The initial performance of all cells was measured by recording IV curves at various temperatures and partial pressure of steam to the Ni/YSZ electrode. Figure 2 shows a comparison of such initial IV curves for the two cells with the highest and the lowest performance, namely, the cells used for tests $\mathrm{B}$ and $\mathrm{C}$. The IV curves shown were recorded at $850^{\circ} \mathrm{C}$ and $p\left(\mathrm{H}_{2} \mathrm{O}\right) / p\left(\mathrm{H}_{2}\right)=1$ and air to the oxygen electrode.

From the IV characteristic shown in Fig. 2, it is observed that no discontinuity occurs in the shift from fuel cell to electrolysis operation. The area specific resistances (ASR) at varying $p\left(\mathrm{H}_{2}\right) / p\left(\mathrm{H}_{2} \mathrm{O}\right)$ ratios at $850^{\circ} \mathrm{C}$ for the cells used for tests $\mathrm{B}$ and $\mathrm{C}$ is given in Table II. It is seen from the numbers in Table II that, even though the slopes of the IV curves in Fig. 2 look identical for positive and negative current densities for each of the two cells, the ASR is larger when running the cells in electrolysis mode than in fuel cell mode. Voltages at distinct current densities were also compared. Both cells had an open-circuit voltage of $928 \mathrm{mV}$ at $850^{\circ} \mathrm{C}$ and $p\left(\mathrm{H}_{2} \mathrm{O}\right) / p\left(\mathrm{H}_{2}\right)=1$. Voltages of 821 and $1061 \mathrm{mV}$ were measured at $0.50 \mathrm{~A} / \mathrm{cm}^{2}$ and $-0.50 \mathrm{~A} / \mathrm{cm}^{2}$, respectively, for the cell with the highest performance (test B). The corresponding values for the cell having the lowest initial performance (test C) were $775 \mathrm{mV}$ and $1091 \mathrm{mV}$ at $0.50 \mathrm{~A} / \mathrm{cm}^{2}$ and $-0.50 \mathrm{~A} / \mathrm{cm}^{2}$.

The effect of temperature on the initial performance of the SOCs has also been investigated. Figure 3 shows an example of the effect of lowering the temperature from 850 to $750^{\circ} \mathrm{C}$ for the good performing cell used for test $\mathrm{B}$. Both curves were recorded at $p\left(\mathrm{H}_{2} \mathrm{O}\right) / p\left(\mathrm{H}_{2}\right)=1$. There is still continuity across OCV for the IV curve at $750^{\circ} \mathrm{C}$ but the ASR has more than doubled compared with the ASR values at $850^{\circ} \mathrm{C}$ (Table II). For the IV curve at $750^{\circ} \mathrm{C}$ in fuel cell mode the ASR is $0.44 \Omega \mathrm{cm}^{2}$. For the IV curve at $750^{\circ} \mathrm{C}$ in electrolysis mode the ASR is $0.65 \Omega \mathrm{cm}^{2}$ if the data to $-0.75 \mathrm{~A} / \mathrm{cm}^{2}$ is included and the chord is used for the calculation of the ASR but

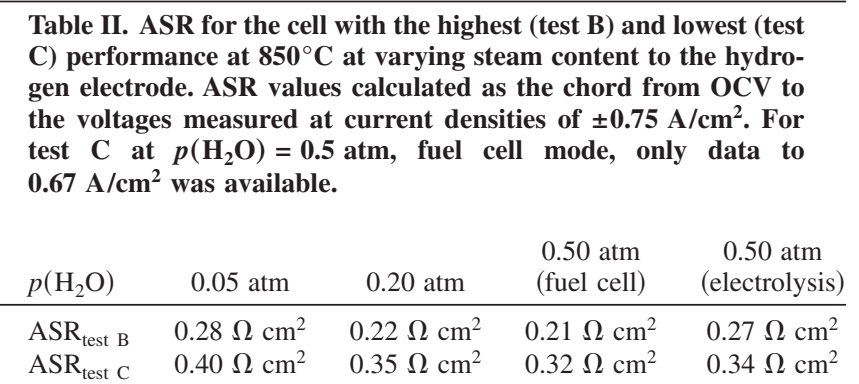




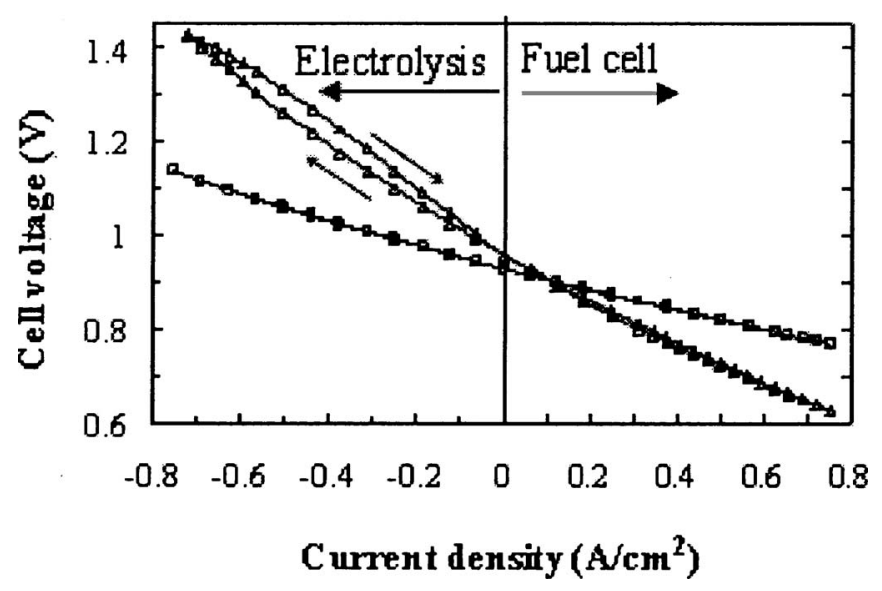

Figure 3. Initial IV curves at $850^{\circ} \mathrm{C}(\square)$ and $750^{\circ} \mathrm{C}(\triangle)$ for the cell used in test B. Arrows indicate direction of time when recording the IV curve at $750^{\circ} \mathrm{C}(\triangle)$.

this number hides the observed hysteresis effect. Calculating the ASR value as the chord from OCV to the voltage measured at a current density of $-0.50 \mathrm{~A} / \mathrm{cm}^{2}$ for the start and end part of the IV curve leads to ASR values of $0.70 \Omega \mathrm{cm}^{2}$ and $0.60 \Omega \mathrm{cm}^{2}$, respectively. The last part of this IV curve represents the more stabile system. The hysteresis effects for this IV curve in electrolysis mode at $750^{\circ} \mathrm{C}$ is of course also clear from the measured voltages at $-0.50 \mathrm{~A} / \mathrm{cm}^{2}$. An open-circuit voltage of $957 \mathrm{mV}$ was measured at $750^{\circ} \mathrm{C}$. Voltages of 1261 and $1309 \mathrm{mV}$ were measured at $-0.50 \mathrm{~A} / \mathrm{cm}^{2}$ for the first and last part of the electrolysis IV curve in Fig. 3. The same four trends have been observed for all cells tested in this work, namely, IV curves at $850^{\circ} \mathrm{C}$ have only minor differences in ASR for fuel cell and electrolysis operation of the cell; no passivation of the cell is observed to take place during electrolysis IV curves at $850^{\circ} \mathrm{C}$, for electrolysis IV curves recorded at $750^{\circ} \mathrm{C}$ a passivation of the cell is observed and the initial performance of the cells is improved at increasing temperatures. iV curves were recorded at 750,850 , and $950^{\circ} \mathrm{C}$.

After the test of the initial performance of each of the SOCs, durability tests at constant galvanostatic electrolysis conditions were conducted. The resulting development of the cell voltages is shown in Fig. 4. For all tests, the cell voltage increased due to an increase in the internal resistance of the cells. The increase in cell voltage had a tendency to take the form of an "S"-curve and level off after $\sim 100 \mathrm{~h}$ of electrolysis or less. The least pronounced passivation over $135 \mathrm{~h}$ of electrolysis was observed for the high-temperature

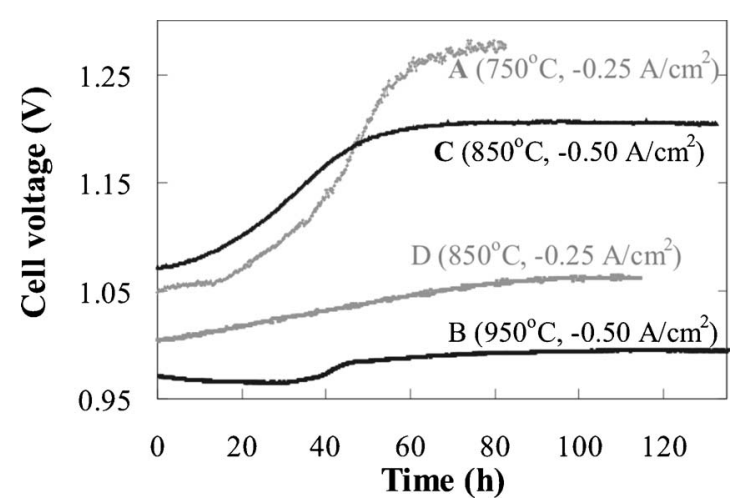

Figure 4. Cell voltage as a function of time at constant electrolysis conditions (Table I). Pure $\mathrm{O}_{2}$ was passed over the positive electrode and the gas composition to the negative electrode was $p\left(\mathrm{H}_{2} \mathrm{O}\right)=0.7$ atm and $p\left(\mathrm{H}_{2}\right)$ $=0.3 \mathrm{~atm}$.

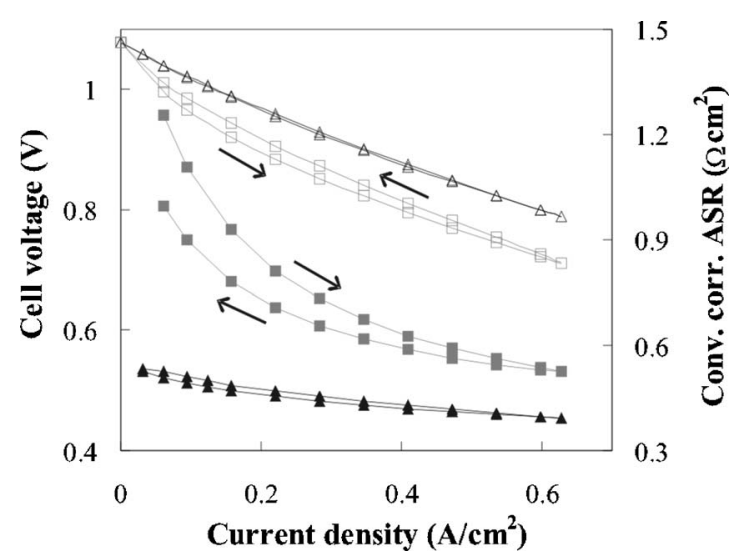

Figure 5. IV curve recorded before $(\triangle)$ and immediately after $(\square)$ electrolysis test A. The IV curves were recorded at $750^{\circ} \mathrm{C}$ and with gas composition of $p\left(\mathrm{H}_{2}\right)=0.95 \mathrm{~atm}$ and $p\left(\mathrm{H}_{2} \mathrm{O}\right)=0.05$ atm to the hydrogen electrode. Arrows indicate direction of time. Open symbols show the cell voltages and closed symbols the conversion corrected ASR values.

test B, which actually started out with a minor activation of the cell. The most significant passivation occurred for test A where the cell voltage increased from 1055 to $1275 \mathrm{mV}$ within only $82 \mathrm{~h}$ of electrolysis. As the cell voltage seems to have stabilized at $1275 \mathrm{mV}$, electrolysis test A was stopped. The development of the polarization resistance monitored by EIS recorded during the pronounced passivation observed for test $\mathrm{A}$ is described and analyzed elsewhere. ${ }^{13}$ Another and a very simple way to monitor the passivation of the cell used for test $\mathrm{A}$ is by comparison of IV curves recorded before and immediately after the electrolysis test and these two IV curves are shown in Fig. 5. The passivation of the cell has led to an increased slope of the IV curve. Data from the IV curve were applied to calculate the conversion corrected ASRs as the internal resistance of the cell depends on test conditions such as the reactant utilization. ${ }^{14}$ The over voltage will not be equal at the gas-inlet and gas-outlet and therefore a conversion correction has been made for the ASR using an iterative calculation method as discussed elsewhere. ${ }^{11}$ The conversion corrected ASRs are included in Fig. 5. A significant hysteresis effect is observed for the IV curve recorded immediately after the electrolysis test A. This hysteresis effect corresponds to a partial activation of the cell obtained during the recording of the IV curve in fuel cell mode after electrolysis test A. In Fig. 5, the direction of time is indicated by arrows. Qualitatively, the course of the cell voltage for test C seems to be similar to that of test A (Fig. 4) but test $\mathrm{C}$ was run for a longer time than test A. Figure 6 shows a

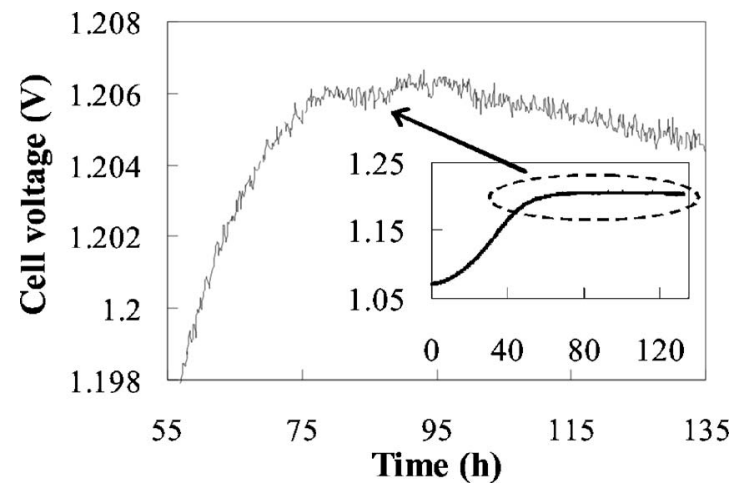

Figure 6. Cell voltage during electrolysis for test $\mathrm{C}\left(850^{\circ} \mathrm{C},-0.5 \mathrm{~A} / \mathrm{cm}^{2}\right)$ emphasizing on the last $80 \mathrm{~h}$ of electrolysis test period where a tendency of decreasing cell voltage corresponding to a decrease in resistance of the cell was observed. 


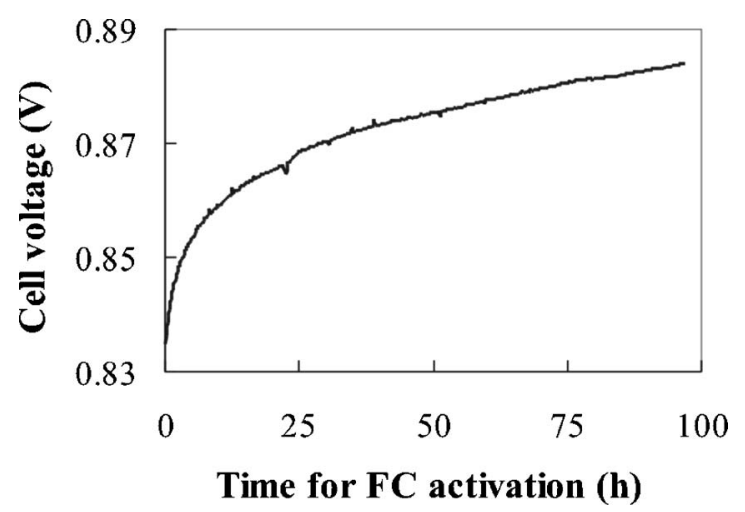

Figure 7. Cell voltage (black line) measured during constant fuel cell operation after electrolysis test $\mathrm{C}$. Conditions during fuel cell operation was: $850^{\circ} \mathrm{C}, 0.5 \mathrm{~A} / \mathrm{cm}^{2}, \mathrm{O}_{2}$ was passed over the oxygen electrode and the gas composition to the hydrogen electrode was $p\left(\mathrm{H}_{2}\right)=0.95$ atm and $p\left(\mathrm{H}_{2} \mathrm{O}\right)$ $=0.05 \mathrm{~atm}$.

"zoom-in" on the development of the cell voltage for test $\mathrm{C}$ from 55 to $135 \mathrm{~h}$ of electrolysis test time. This reveals that a decrease in the cell voltage corresponding to a decrease in the internal resistance of the cell took place at the end of the test. Electrolysis test $\mathrm{C}$ was stopped unintentionally due to a failure in steam supply causing steam starvation for the electrolysis process. After ending test $\mathrm{C}$, the cell was run at constant fuel cell condition at $8500^{\circ} \mathrm{C}$, a current density of $0.5 \mathrm{~A} / \mathrm{cm}^{2}$ and $p\left(\mathrm{H}_{2}\right) / p\left(\mathrm{H}_{2} \mathrm{O}\right)=0.95 / 0.05$ as inlet gas composition to the hydrogen electrode. Figure 7 shows that the cell voltage increased by $49 \mathrm{mV}$ during the $97 \mathrm{~h}$ of constant fuel cell operation of the cell and this correspond to a partial activation of cell $\mathrm{C}$. Test $\mathrm{D}$ was run at even milder conditions than test $\mathrm{C}$, in the sense that the current density was lowered to $-0.25 \mathrm{~A} / \mathrm{cm}^{2}$. Figure 4 only shows the cell voltage for the first part of test $\mathrm{D}$, although this test was run for a total electrolysis time of $766 \mathrm{~h}$ at constant conditions, and the course of the cell voltage over the entire electrolysis test period is shown in Fig. 8. The cell voltage increased from 1004 to $1062 \mathrm{mV}$ within the first $116 \mathrm{~h}$ of electrolysis at constant conditions corresponding to a passivation of the cell. Hereafter, the cell voltage decreased to $1017 \mathrm{mV}$ over the next $651 \mathrm{~h}$, corresponding to a decrease in the internal resistance of the cell. In total, the cell voltage only increased by $13 \mathrm{mV}$ over $766 \mathrm{~h}$ of electrolysis at constant electrolysis conditions. Impedance spectra were recorded during electrolysis test $\mathrm{D}$. The values of the polarization resistances $\left(R_{\mathrm{p}}\right)$ derived from these EIS are included in Fig. 8. $R_{\mathrm{p}}$ increased from 0.16 to $0.46 \Omega \mathrm{cm}^{2}$ and hereafter decreased to $0.22 \Omega \mathrm{cm}^{2} . R_{\mathrm{s}}$ was constant during the entire electrolysis test D. An overview of some of the measured values for $R_{\mathrm{p}}$ and $R_{\mathrm{S}}$ is given in Table III. The development of the impedance spectra during electrolysis test $\mathrm{D}$ is shown in Fig. 9. The EIS in Fig. 9 were recorded after 1, 45, 116, and $317 \mathrm{~h}$ of electrolysis and these spectra have the $R_{\mathrm{p}}$ values indicated by the closed triangles in Fig. 8. The spectrum recorded after $45 \mathrm{~h}$ of electrolysis is during passivation of the cell and the spectrum recorded after $317 \mathrm{~h}$ of electrolysis testing is during activation of the cell. The maximum $R_{\mathrm{p}}$ was obtained after $116 \mathrm{~h}$ of electrolysis. The complete overlap of the EIS recorded after 45 and $317 \mathrm{~h}$ of electrolysis testing at constant conditions should be noticed. The

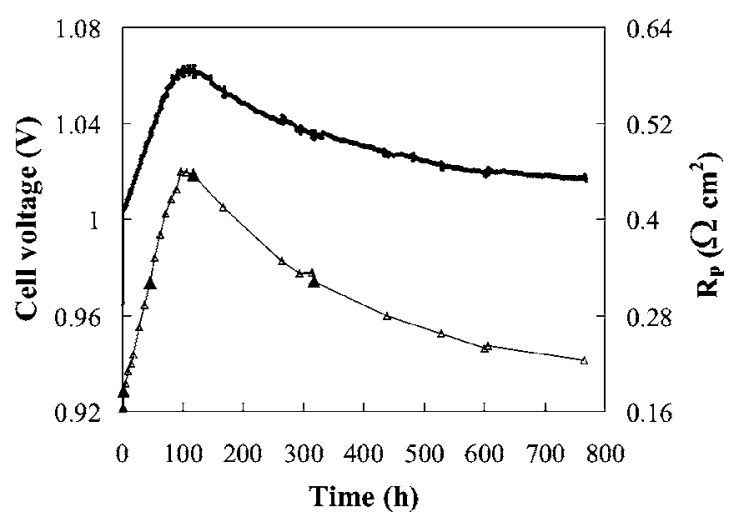

Figure 8. Cell voltage and polarization resistance $R_{\mathrm{p}}(\triangle)$ for test D as a function of time. Experimental conditions were constant at $-0.25 \mathrm{~A} / \mathrm{cm}^{2}$, $850^{\circ} \mathrm{C}, p\left(\mathrm{H}_{2} \mathrm{O}\right)=0.7 \mathrm{~atm}$ and $p\left(\mathrm{H}_{2}\right)=0.3 \mathrm{~atm}$ to the hydrogen electrode and $\mathrm{O}_{2}$ was passed over the oxygen electrode. Closed symbols for $R_{\mathrm{p}}$ correspond to the impedance spectra shown in Fig. 9.

Nyquist and the Bode plots show that $R_{s}$ stays constant during the entire electrolysis test D. From the imaginary part of the Bode plot in Fig. 9, it is observed that numeric maximum for $Z_{\text {imag }}$ decreases from a frequency of ca. $7 \mathrm{kHz}$ after $1 \mathrm{~h}$ of electrolysis to a frequency of $\sim 2 \mathrm{kHz}$ after $45 \mathrm{~h}$ of electrolysis and down to $\sim 400 \mathrm{~Hz}$ at the most passivated state after $116 \mathrm{~h}$ of electrolysis testing. Furthermore, the imaginary part of the Bode plot shows minor increase/ decrease in $Z_{\text {imag }}$ for the impedance at a frequency of $1-5 \mathrm{~Hz}$, which is ascribed to gas conversion impedance. ${ }^{15}$

In Fig. 10, the IV curves $\left(850^{\circ} \mathrm{C}, p\left(\mathrm{H}_{2} \mathrm{O}\right)=0.46 \mathrm{~atm}\right.$ and $p\left(\mathrm{H}_{2}\right)=0.53 \mathrm{~atm}$, air to the oxygen electrode) in fuel cell and electrolysis operation before and after electrolysis test D is shown. Only a limited increase in the ASR is observed for the IV curve after electrolysis test D. The difference in the slope of the IV curves is slightly larger for electrolysis mode than for fuel cell mode. Figure 11 shows two fuel cell mode IV curves recorded just before electrolysis test D and immediately after finishing the electrolysis operation of the cell. These IV curves are almost identical. The partial activation of the cell that was caused by recording a fuel cell IV curve immediately after test A (Fig. 5), was not observed for this test $D$. IV curves for test $\mathrm{D}$ were also recorded at the same conditions as those for test A in Fig. 5 (fuel cell operation, $750^{\circ} \mathrm{C}, p\left(\mathrm{H}_{2} \mathrm{O}\right)$ $=0.05 \mathrm{~atm}$ and $\left.p\left(\mathrm{H}_{2}\right)=0.95 \mathrm{~atm}\right)$. For those IV curves, the ASR increased from $0.54 \Omega \mathrm{cm}^{2}$ before test to $0.61 \Omega \mathrm{cm}^{2}$ after the electrolysis test but no noticeable activation effect was observed for the fuel cell mode IV curve recorded after electrolysis test D.

\section{Discussion}

Initial performance of the SOECs.- The continuity of the IV curves (Fig. 2 and 3) close to OCV verifies that even though these cells were produced and optimized for fuel cell use, they can work as reversible SOCs. In general the initial ASR obtained from IV curves was lower in fuel cell mode than in electrolysis mode (Table II). Table IV lists some initial performances obtained from IV curves in electrolysis mode for SOECs reported in literature. As discussed by Mogensen et al. ${ }^{14}$ the concept of area specific resistance for

Table III. $R_{\mathrm{s}}, R_{\mathrm{p}}$ and increase in $R_{\mathrm{p}}$ relative to $R_{\mathrm{p}}$ after $1 \mathrm{~h}$ of electrolysis for test D. $R_{\mathrm{s}}$ is taken as the real part of the impedance at $82 \mathrm{kHz}$ and $R_{\mathrm{p}}$ is taken as the real part of the impedance at $0.82 \mathrm{~Hz}$ minus $R_{\mathrm{s}}$.

\begin{tabular}{lcccc} 
Time & $1 \mathrm{~h}$ & $45 \mathrm{~h}$ & $116 \mathrm{~h}$ & $317 \mathrm{~h}$ \\
\hline$R_{\mathrm{S}}$ & $0.131 \Omega \mathrm{cm}^{2}$ & $0.135 \Omega \mathrm{cm}^{2}$ & $0.133 \Omega \mathrm{cm}^{2}$ & $0.132 \Omega \mathrm{cm}^{2}$ \\
$R_{\mathrm{p}}$ & $0.163 \Omega \mathrm{cm}^{2}$ & $0.321 \Omega \mathrm{cm}^{2}$ & $0.455 \Omega \mathrm{cm}^{2}$ & $0.126 \Omega \mathrm{cm}^{2}$ \\
$R_{\mathrm{p}} / R_{\mathrm{p}}(1 \mathrm{~h})$ & 1 & 2.0 & 2.7 & $0.322 \Omega \mathrm{cm}^{2}$ \\
& & & 2.0 & $0.224 \Omega \mathrm{cm}^{2}$
\end{tabular}



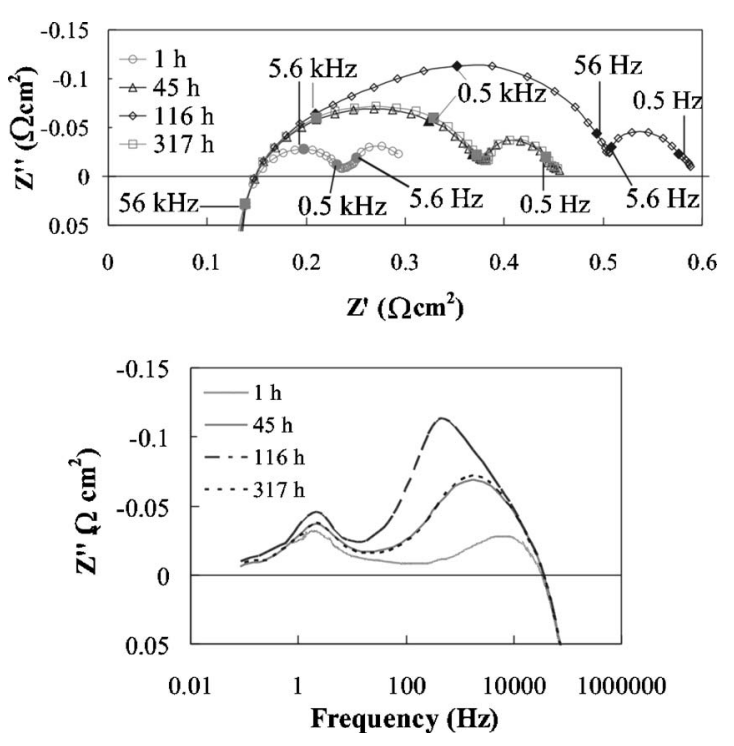

Figure 9. Impedance spectra recorded after 1, 45, $116\left(\max R_{\mathrm{p}}\right)$, and $317 \mathrm{~h}$ of electrolysis at constant conditions for test D (Table I). The spectrum recorded after $45 \mathrm{~h}$ of electrolysis was during passivation of the cell while the spectrum recorded after $317 \mathrm{~h}$ of electrolysis was during the subsequent activation of the cell that happened over time at the same constant electrolysis conditions as during the initial passivation. The closed symbols in the Nyquist plot indicate the different frequencies.

SOFCs is often used, though no generally accepted definition seems to exist. Because the ASR depends on fuel utilization, a more direct description of the cell performance is given by the conversion corrected ASRs (Fig. 5 and 11). Unfortunately, conversion corrected ASRs or information enabling the calculation of it, is not always reported in literature. Therefore, the listing of ASRs given in Table IV is simply obtained by taking the slopes of the reported IV curves in the linear regions. The references in Table IV have been selected as they represent results for cells and test conditions close to those applied for the IV curves for the cells tested in this work. Table IV shows that the reversible SOCs produced at Ris $\varnothing$ National Laboratory have the best initial performance.

Only a few of the results on full electrolysis cells reported in literature include long-term testing and, therefore, a comparison of the long-term electrolysis testing results presented here with results for similar electrolysis cells is difficult. One of the few successful long-term electrolysis tests was reported by Dönitz et al. ${ }^{16}$ They ran a $1000 \mathrm{~h}$ single cell test at $1000^{\circ} \mathrm{C}$ and no notable passivation was observed. But it should be pointed out that the microstructure of

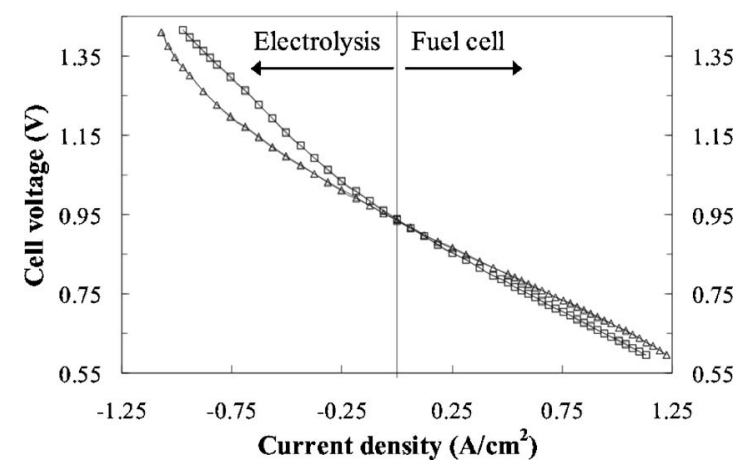

Figure 10. IV curves recorded before $(\triangle)$ and after $(\square) 766 \mathrm{~h}$ of electrolysis at constant conditions, test $\mathrm{D}$. The experimental conditions when recording the IV urves were $850^{\circ} \mathrm{C}, p\left(\mathrm{H}_{2} \mathrm{O}\right)=0.46$ atm and $p\left(\mathrm{H}_{2}\right)=0.53$ atm at the negative electrode and air at the positive electrode.

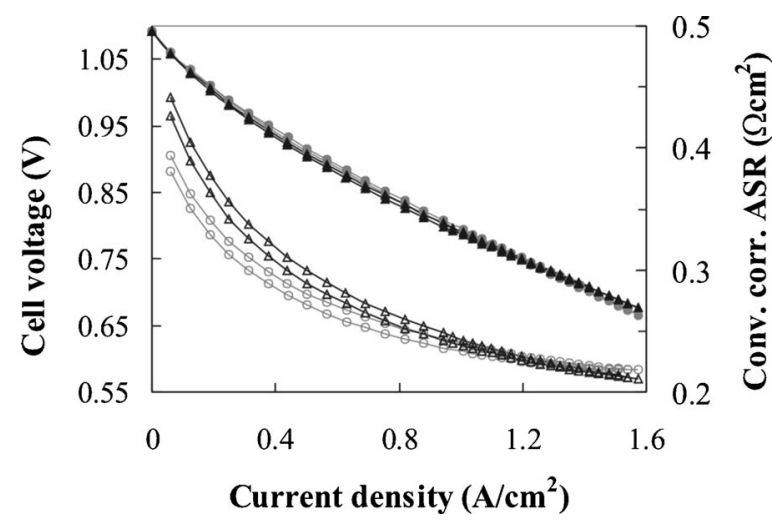

Figure 11. Fuel cell mode IV curves recorded just before $(\bigcirc)$ and immediately after $(\triangle) 766 \mathrm{~h}$ of electrolysis test $\mathrm{D}$. The experimental conditions for the IV curves were $850^{\circ} \mathrm{C}, p\left(\mathrm{H}_{2} \mathrm{O}\right)=0.05$ atm and $p\left(\mathrm{H}_{2}\right)=0.95$ atm and pure oxygen was passed over the oxygen electrode. Closed symbols show the cell voltages and open symbols the conversion corrected ASRs.

their electrodes was more coarse than for the SOECs tested in this work, and the starting point for their testing, that is the initial ASRs for their cells at $1000^{\circ} \mathrm{C}$, was even larger than the ASR that was measured for Ris $\varnothing$ cells at $850^{\circ} \mathrm{C}$ (test D) after the partly passivation during the $766 \mathrm{~h}$ of electrolysis test.

Long-term galvanostatic electrolysis tests at various temperatures and current densities. - In view of the fact that the cells are from the same production batch and have very similar initial performance (Fig. 2), the development of the cell voltages in Fig. 4 illustrates the effect of variation of the temperature and the current density for the electrolysis tests. Comparing test A and D, the only difference is the temperature of $750^{\circ}$ and $850^{\circ} \mathrm{C}$, respectively. The difference in temperature for the two tests gives rise to a considerable difference in the increase of the cell voltage. While the cell voltage for test $\mathrm{D}$ only increased by $58 \mathrm{mV}$ over $116 \mathrm{~h}$, the increase was $220 \mathrm{mV}$ over $82 \mathrm{~h}$ for the low-temperature test $\mathrm{A}$. The same trend for the increase in cell voltages is seen when comparing test $\mathrm{B}$ $(30 \mathrm{mV}$ from $t=30 \mathrm{~h}$ to $t=135 \mathrm{~h})$ and test $\mathrm{C}(135 \mathrm{mV}$ over $92 \mathrm{~h})$, where the only difference in operation conditions were the temperatures of 850 and $950^{\circ} \mathrm{C}$, respectively. The effect of changing the current density is seen by comparing test $\mathrm{C}$ and $\mathrm{D}$. The same inlet gas composition was applied but changing the current density from $-0.25 \mathrm{~A} / \mathrm{cm}^{2}$ to $-0.50 \mathrm{~A} / \mathrm{cm}^{2}$ also changed the steam utilization from $14 \%$ to $28 \%$.

Previously, Jensen ${ }^{17}$ found evidence for a build-up of impurities containing silicon at the three-phase-boundary (TPB) for a Ni-YSZ model system and $\mathrm{Liu}^{18}$ found segregated silicon containing impurities in a tested half cell by scanning and transmission electron microscopy. Such a build-up of impurities could lead to an increase in cell voltage as observed in Fig. 4, where the cell voltage curve levels off when the impurity build-up at the Ni-YSZ TPB stops (all impurities collected). A subsequent decrease in the cell voltage could be due to a conversion of the impurity phase, e.g., crystallization of the glass, see below. The tendency for the course of the cell voltage for all four tests to take the form of "S-curves" supports the explanation for the passivation of the electrolysis cells given by Jensen et al. ${ }^{13}$ By deconvolution of the EIS recorded during electrolysis, it was shown that the rate limiting step for the steam electrolysis using SOCs was due to a process at the TPB in the Ni/YSZ electrode and it was argued that it is related to an increase in the diffusion path length during the passivation of the electrolysis cell. This phenomenon was explained as impurities building up at the TPB in the Ni/YSZ.

Activation of an electrolysis cell.- To the best of our knowledge, the passivation of an electrolysis cell followed by a partial 


\begin{tabular}{|c|c|c|c|c|c|}
\hline Ref. & $\begin{array}{c}T \\
{\left[{ }^{\circ} \mathrm{C}\right]}\end{array}$ & $\begin{array}{c}p\left(\mathrm{H}_{2} \mathrm{O}\right) \\
{[\mathrm{atm}]}\end{array}$ & $\begin{array}{l}p\left(\mathrm{H}_{2}\right) \\
{[\mathrm{atm}]}\end{array}$ & $\begin{array}{c}\mathrm{ASR} \\
{\left[\Omega \mathrm{cm}^{2}\right]}\end{array}$ & Specifications \\
\hline $\begin{array}{l}\text { This } \\
\text { work }\end{array}$ & 850 & 0.50 & 0.50 & 0.27 & Ni/YSZ-YSZ-LSM (planar 2G DK-SOFC), test B \\
\hline $\begin{array}{l}\text { This } \\
\text { work }\end{array}$ & 950 & 0.50 & 0.50 & 0.15 & Ni/YSZ-YSZ-LSM (planar 2G DK-SOFC), test B \\
\hline 16 & 1000 & 0.67 & 0.33 & 1.17 & Ni/YSZ-YSZ-LSM (tubular cell) \\
\hline 19 & 908 & 0.67 & 0.33 & $2.7^{\mathrm{a}}$ & Ni/YSZ-YSZ-LSM. 32 cell stack-tubular cells. \\
\hline 20 & 1000 & 0.91 & 0.09 & 2 & Ni/YSZ-YSZ-LSM \\
\hline 21 & 1000 & 0.50 & 0.50 & 0.7 & $\mathrm{Ni} / Y S Z-Y S Z-L S M$ \\
\hline 22 & 850 & 0.50 & 0.50 & 0.45 & Ni/YSZ-ScSZ (175 $\mu \mathrm{m})-\mathrm{LSM}$ \\
\hline 23 & 900 & 0.50 & 0.50 & 1.8 & $\begin{array}{l}\text { Figure } 2 \text { in Ref. } 23 \text { was used to estimate the ASR for } \\
\text { the full cell. }\end{array}$ \\
\hline 24 & 850 & 0.11 & 0.89 & 0.35 & Ni/YSZ-ScSZ (125 $\mu \mathrm{m})$-LSM \\
\hline
\end{tabular}

${ }^{a}$ The ASR given is the average per cell in the stacks. The numbers calculated from the IV curves have been reduced by $31 \%$ to correct for the resistance due to interconnect. The reduction by $31 \%$ was estimated by comparison of single cell and stack test at the same conditions as they were reported in Ref. 16 .

activation at constant electrolysis conditions, as obtained for electrolysis test $\mathrm{D}$, has not been reported for solid oxide electrolysis cells previously. This phenomenon has been observed for several of the electrolysis tested cells. Furthermore, the EIS recorded during this long-term electrolysis test D did not only lead to polarization resistances being equal during passivation and the subsequent activation of the cell; the EIS with the same $R_{\mathrm{p}}$ recorded during passivation and activation are identical at each measured frequency (Fig. 9). This strongly suggests that it is the same processes that are the rate limiting steps both during the passivation and the following activation of the electrolysis cell. The analysis of the EIS during electrolysis for the first $116 \mathrm{~h}$ points towards that the rate limiting step responsible for the passivation of the cell can be diffusion at the TPB caused by an increased diffusion path length. ${ }^{13}$ If the passivation of the cell used for test $\mathrm{D}$ is due to a build-up of glassy phase impurities at the TPB of the hydrogen electrode, then a plausible, but not yet experimentally verified, explanation for the subsequent partial activation of the cell could be a break-up of the glass caused by crystallization of these glassy phases. Such break-up would lead to a decrease in the diffusion path length and enable the complete overlap of the EIS recorded during passivation and activation of the cell as observed in Fig. 9. Impurities containing silica have been observed by scanning electron microscopy and detected by energy dispersive spectroscopy in the hydrogen electrode of the electrolysis tested cells. Further microscopy work is in progress. The partial activation of the cell by running an IV curve in fuel cell mode after the electrolysis test has not only been observed for test A but also for other tests, where a fuel cell IV curve was recorded immediately after a significant passivation in electrolysis operation. For the IV curve recorded after electrolysis test A (Fig. 5), the conversion corrected ASR decreased by $20 \%$ at a current density of $-62.5 \mathrm{~mA} / \mathrm{cm}^{2}$ and this activation occurred within the $22 \mathrm{~min}$ it took to record the entire IV curve. This activation of the cell is possibly of a nature different from that of the activation observed for test $\mathrm{D}$. The activation due to FC operation is governed by the change in current direction, e.g., a change in the direction of $\mathrm{O}^{2-}$ ions conducted in the electrolyte and a change in the $p\left(\mathrm{H}_{2} \mathrm{O}\right)$ gradient in the $\mathrm{Ni} / \mathrm{YSZ}$ electrode. Impurities can be removed from the TPB and transported towards the bulk of the composite Ni-YSZ electrode, i.e., away from the interface at the electrolyte where the electrochemistry happens. This fuel-cell-activation of the cell takes place on a much shorter time scale than the activation of the cell in test $\mathrm{D}$, where a $51 \%$ reduction in $R_{\mathrm{p}}$ was obtained during $651 \mathrm{~h}$ of constant electrolysis conditions. Considering the partial activation of cell A by running an iV-curve in fuel cell mode after electrolysis passivation, it is not surprising that a partial activation of a SOC after electrolysis testing can also be obtained by operating the cell at constant fuel cell conditions as observed for cell C (Fig. 7). For the activation of the cell at constant fuel cell operation, the time scale is again shorter than for the activation observed for test $\mathrm{D}$ at constant electrolysis conditions. For test D the $R_{\mathrm{p}}$ had already dropped to half its maximum value when the long-term test was stopped after $766 \mathrm{~h}$ of electrolysis, and no further activation due to recording an IV curve in fuel cell mode could be obtained (Fig. 11).

\section{Conclusion}

From the results presented here using DK-SOFCs for high temperature electrolysis of steam it can be concluded that:

The cells produced at Ris $\varnothing$ National Laboratory can be operated both as fuel cells and electrolysis cells.

The area specific resistance obtained from the IV curves run in electrolysis mode was higher than for fuel cell IV curves for the same cells.

The IV curves show that the SOECs tested in this work performs very well compared with similar SOECs reported in literature.

At constant galvanostatic electrolysis conditions, the internal resistance of the cells increased significantly during the first $\sim 100 \mathrm{~h}$, after which the cell voltage stabilized or even decreased.

For the most passivated cell (test $\mathrm{A},-0.25 \mathrm{~A} / \mathrm{cm}^{2}, 750^{\circ} \mathrm{C}, 82 \mathrm{~h}$ of electrolysis), a partial activation of the cell was obtained by running an IV curve in fuel cell mode immediately after electrolysis life-time test.

A cell that has been passivated during electrolysis can at least be partly activated by operating the cell at constant fuel cell conditions.

For test $\mathrm{D}\left(-0.25 \mathrm{~A} / \mathrm{cm}^{2}, 850^{\circ} \mathrm{C}, 766 \mathrm{~h}\right.$ of electrolysis), a partial activation of the cell following the initial passivation was observed when operated at constant galvanostatic electrolysis conditions.

\section{Acknowledgment}

This work was supported by the EC via the project "Hi2H2" contract no. FP6-503765. Thanks to the Fuel Cell group and to senior scientist J. Bilde-Sørensen, Materials Research Department, at Risø National Laboratory for their help and assistance.

Ris $\phi$ National Laboratory assisted in meeting the publication costs of this article.

\section{References}

1. A. O. Isenberg, Solid State Ionics, 3-4, 431 (1981).

2. W. Dönitz and R. Schmidberger, Int. J. Hydrogen Energy, 7, 321 (1982).

3. W. Dönitz, E. Erdle, and R. Streicher, in Electrochemical Hydrogen Technologies. 
Electrochemical Production and Combustion of Hydrogen, p. 213, Elsevier, London (1990).

4. S. H. Jensen and M. Mogensen, Paper presented at the 19th World Energy Congress, London, England, 2004.

5. A. Hagen, R. Barfod, P. V. Hendriksen, Y.-L. Liu, and S. Rasmousse, in Solid Oxide Fuel Cells IX, S. C. Singhal and J. Mizusaki, Editors, PV 2005-07, p. 503, The Electrochemical Society Proceedings Series, Pennington, NJ (2005).

6. A. Hagen, R. Barfod, P. V. Hendriksen, Y.-L. Lin, and S. Ramousse, J. Electrochem. Soc., Submitted.

7. P. H. Larsen, C. Bagger, S. Linderoth, M. Mogensen, S. Primdahl, M. J. Jørgensen, P. V. Hendriksen, B. Kindl, N. Bonanos, F. W. Poulsen, and K. A. Maegaard, in Solid Oxide Fuel Cells VII, H. Yokokawa and S. C. Singhal, Editors, PV 2001-16, p. 28, The Electrochemical Society Proceedings Series, Pennington, NJ (2001).

8. C. Bagger, in Fuel Cell Seminar, C. E. Pax, Editor p. 241, Courtesy Associations, Inc., Washington, DC (1992)

9. M. J. Jorgensen and M. Mogensen, J. Electrochem. Soc., 148, A433 (2001).

10. R. Barfod, S. Koch, Y.-L. Liu, P. H. Larsen, and P. V. Hendriksen, in Solid Oxide Fuel Cells VIII, S. C. Singhal and M. Dokiya, Editors, PV 2003-07, p. 1158, The Electrochemical Society Proceedings Series, Pennington, NJ (2003).

11. M. Mogensen and P. V. Hendriksen, in High Temperature Solid Oxide Fuel CellsFundamentals, Design and Applications, p. 261, Elsevier, London (2003).

12. J. R. Macdonald and E. Barsoukov, Impedance Spectroscopy. Theory, Experiment, and Applications, John Wiley \& Sons, Inc., Hoboken, NJ (2005).
13. S. H. Jensen, A. Hauch, M. Mogensen, T. Jacobsen, and I. Chorkendorff, J. Electrochem. Soc., Submitted.

14. M. Mogensen, P. H. Larsen, P. V. Hendriksen, B. Kindl, C. Bagger, and S. Linderoth, in Solid Oxide Fuel Cells VI, S. C. Singhal and M. Dokiya, Editors, PV 99-19, p. 904, The Electrochemical Society Proceedings Series, Pennington, NJ (1999).

15. S. Primdahl and M. Mogensen, J. Electrochem. Soc., 145, 2431 (1998)

16. W. Dönitz and E. Erdle, Int. J. Hydrogen Energy, 10, 291 (1985).

17. K. V. Jensen, R. Wallenberg, I. Chorkendorff, and M. Mogensen, Solid State Ionics, 160, 27 (2003)

18. Y.-L. Liu and C. Jiao, Solid State Ionics, 176, 435 (2005).

19. E. Erdle, W. Dönitz, R. Schaumm, and A. Koch, Int. J. Hydrogen Energy, 17, 817 (1992).

20. K. Eguchi, T. Hatagishi, and H. Arai, Solid State Ionics, 86-88, 1245 (1996).

21. A. Momma, T. Kato, Y. Kaga, and S. Nagata, J. Ceram. Soc. Jpn., 105, 369 (1997).

22. J. S. Herring, P. Lessing, J. E. O'Brien, C. Stoots, J. Hartvigsen, and S. Elangovan in Second Information Exchange Meeting on Nuclear Production of Hydrogen, p. 1, Argonne National Laboratory, Argonne, IL (2003).

23. H. Uchida, Electrochem. Solid-State Lett., 7, A500 (2004).

24. J. E. O'Brien, C. M. Stoots, J. S. Herring, P. A. Lessing, J. J. Hartvigsen, and S. Elangovan, in Proceedings of ICONE12, 12th International Conference on Nuclear Engineering (2004). 